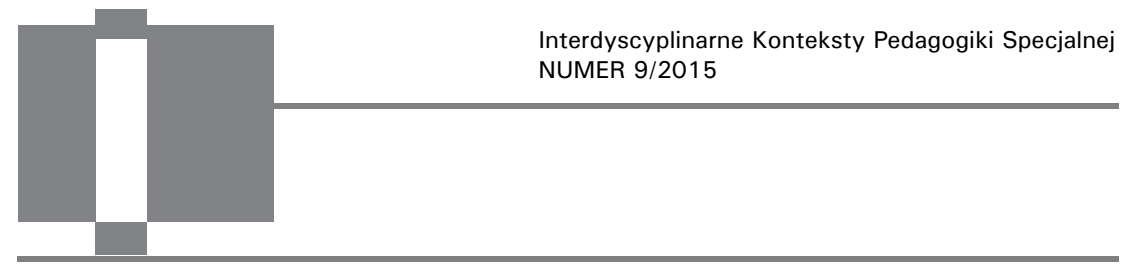

\title{
Agnieszka Wołowicz-Ruszkowska, Zanikanie. Trajektorie tożsamości kobiet z niepełnosprawnością, Wydawnictwo Akademii Pedagogiki Specjalnej, Warszawa 2013.
}

Autorka recenzowanej rozprawy - Agnieszka Wołowicz-Ruszkowska jest doktorem nauk humanistycznych, pedagogiem i psychologiem na stanowisku adiunkta w Instytucie Pedagogiki Specjalnej Akademii Pedagogiki Specjalnej im. Marii Grzegorzewskiej w Warszawie. W ramach swoich zainteresowań poznawczych zajmuje się kontekstem społeczno-kulturowym funkcjonowania osób $\mathrm{z}$ niepełnosprawnością. Interesuje ją szczególnie rola wydarzeń trajektoryjnych w życiu człowieka, problematyka nierówności społecznych, jak również zastosowanie metod jakościowych w badaniach nad rzeczywistością społeczną. W tym zakresie współpracuje z Agency of Development In Special Needs Education oraz z Helsińską Fundacją Praw Człowieka w Gruzji. Omawiana przeze mnie książka stanowi publikację rozprawy doktorskiej tej autorki. Agnieszka Wołowicz-Ruszkowska zajęła się w niej badaniami jakościowymi nad tożsamością kobiet, które urodziły się z niepełnosprawnością bądź też uległy niepełnosprawności w pewnym momencie życia. Publikacja dzieli się na trzy części, przy czym pierwszą stanowi rozdział teoretyczny, druga poświęcona jest metodologii badań, a trzecia prezentacji i omówieniu wyników.

W części pierwszej pt. Definicje i konteksty pojęcia tożsamości autorka dokonała prezentacji wybranych koncepcji związanych z problematyką tożsamości, kładąc nacisk na sposób jej kształtowania. Rozdział pierwszy rozpo- 
czyna ukazaniem modeli tożsamości Zbigniewa Bokszańskiego. Następnie zajmuje się motywem włóczęgi Zygmunta Baumana, odnosząc go do sytuacji osoby niepełnosprawnej oraz koncepcją cieni miasta Arnolda Midnela, odnosząc ją do osób niepełnosprawnych jako zbiorowości. Dwa ostatnie podrozdziały poświęcone są narracji jako sposobowi kreowania tożsamości. To fragment, w którym autorka śledzi tożsamość narracyjną w ramach trzech różnych ujęć - społeczno-konstrukcjonistycznym, poznawczo-konstrukcjonistycznym i psychologiczno-dyskursywnym oraz zajmuje się pamięcią autobiograficzną i jej znaczeniem dla przebiegu procesów tożsamościowych. W rozdziale drugim, Konteksty $i$ warunki ksztattowania się tożsamości niepetnosprawnych kobiet, czytelnik znajdzie omówienie koncepcji osób marginalizowanych Ervinga Goffmana oraz teorii społecznej kategoryzacji Susan Fiske, a następnie rekonstrukcję koncepcji trajektorii Anselma Straussa, Fritza Schützego i Gerharda Riemanna. Środkowa, metodologiczna, część omawianej pracy, zatytułowana Przyjęta strategia i metodologia badań, rozpoczyna się od omówienia feministycznego podejścia w badaniach naukowych. Po nim następuje uzasadnienie wyboru badań jakościowych jako metody studiowania sytuacji kobiet niepełnosprawnych. Autorka zapoznaje czytelnika z zasadą teoretycznego doboru próby, którą zastosowała w swojej pracy badawczej, a prócz tego informuje, w jaki sposób wzmacniała trafność badań oraz rzetelność danych, wyjawia cel badań i prezentuje zadanie badawcze. Drugi rozdział części metodologicznej poświęcony jest badaniom biograficznym. Dowiadujemy się z niego, jaka myśl socjologiczna leży u podstaw tej metody badań, a ściśle - poznajemy koncepcję współczynnika humanistycznego Floriana Znanieckiego oraz koncepcje socjologiczne: biografistyczną Schützego i interakcjonistyczną Straussa. Po tym wprowadzeniu autorka przedstawia główne założenia metody wywiadu autobiograficznego Schützego. W trzecim rozdziale metodologicznym badaczka pochyla się nad fenomenem narracji oraz prezentuje zastosowaną $\mathrm{w}$ niniejszej pracy metodę autobiograficznego wywiadu narracyjnego. Poznajemy nie tylko założenia teoretyczne tej metody, ale także przebieg wywiadów z Respondentkami, dzięki czemu czytelnik zyskuje wiedzę, w jaki sposób został zgromadzony materiał badawczy. $W$ niniejszym rozdziale dowiadujemy się także, w jaki sposób autorka analizowała zebrany materiał, począwszy od wyłonienia fragmentów narracyjnych aż do uzyskania „wzorów przebiegów biograficznych" (s. 121). Na końcu części drugiej autorka przedkłada czytelnikowi pytania badawcze, a także opisuje próbę badawczą, informując o ilości przebadanych kobiet, ich wieku, miejscu zamieszkania oraz rodzajach niepełno- 
sprawności. W części trzeciej, Tożsamość niepetnosprawnych kobiet $i$ ich trajektorie biograficzne, następuje prezentacja wyników badań oraz końcowych wniosków. Część ta rozpoczyna się od analizy sposobu, w jaki kobiety kształtują narracje o swoim życiu, ze szczególnym uwzględnieniem momentu przechodzenia od sprawności do niesprawności jako momentu kluczowego w życiu każdej z Respondentek. Badaczka ukazuje pojawiającą się (bądź gwałtownie postępującą) niepełnosprawność $\mathrm{w}$ perspektywie rozłamu $\mathrm{w}$ tożsamości, związanego z niekontrolowanym nadejściem cierpienia i koniecznością przebudowy życia, a tym samym - przebudowy tożsamości. Przy okazji tych rozważań zostaje ujawniony rozwojowy aspekt opisywanych wydarzeń. O tym, „czy doświadczenie jest spostrzegane i interpretowane jako rozwijające, czy nie” - czytamy - "decyduje interpretacja zaistniałego zdarzenia oraz wymiar aktywności kobiet i poczucie tożsamości osobistej dające mocną podstawę do rozpoczęcia konstruktywnych przekształceń osobowościowych" (s. 163). W rozdziale drugim czytamy o cielesności kobiet niepełnosprawnych. Przed omówieniem wyników badań autorka zdecydowała się umieścić rozważania teoretyczne, ponieważ potrzeba pochylenia się nad cielesnym aspektem niepełnosprawności pojawiła się już po zakończeniu prac nad właściwą częścią teoretyczną $W$ antropologicznych rozważaniach nad cielesnością znajdujemy ujęcie ciała jako tekstu kultury, a także kategorię trzeciej płci, oznaczającą w omawianym kontekście kobietę niepełnosprawną wyrzuconą poza kategorie kobiecości i męskości. Zostaje tu podkreślona nieobecność ciał niepełnosprawnych kobiet oraz towarzysząca jej nadreprezentacja ciał pięknych, kompletnych i zdrowych w dyskursie medialnym. W dalszych analizach autorka omawianej rozprawy wyodrębnia i opisuje trzy typy myślenia kobiet o własnej niepełnosprawności: „poddanie się niewidzialności” (s. 189), „próby dopasowania się do przyjętych wzorców” (s. 190) oraz „usunięcie granicy pomiędzy osobą zdrową a niepełnosprawną" (s. 192). Rozdział trzeci dotyczy znaczenia środowiska, zwłaszcza rodzinnego, w kształtowaniu się tożsamości kobiet $\mathrm{z}$ niepełnosprawnością, dotyka też wpływu niepełnosprawności na zawieranie związków osobistych, w tym - związków o charakterze seksualnym. Analizie zostają poddane także reakcje społeczne na fizyczne oznaki niepełnosprawności u kobiet. Wśród tych reakcji autorka wyróżnia zachowania "przyzwalające”, "przyzwalająco-zakazujące” (s. 246) oraz „zakazujące” (s. 247). W rozdziale czwartym badaczka śledzi strategie włączania nowego obrazu siebie jako osoby z niepełnosprawnością do tożsamości. Wyróżnia tożsamość „kontestującą" (s. 250), „odrzucającą", "gniewną" (s. 253), konfliktową" oraz tożsamość 
"realistyczną" (s. 256) - która odznacza kobiety pogodzone z własnym losem. Rozdział piąty stanowi podsumowanie pracy. W nim autorka zwraca uwagę, że opowieść o niepełnosprawności to dla większości kobiet „najważniejsza opowieść w życiu”, "matryca dla innych opowieści” (s. 288) i klucz do interpretacji świata. Podkreśla, iż przeżywanie niepełnosprawności powoduje zmiany w obrębie tożsamości, porównując sytuację niepełnosprawnych kobiet do sytuacji wędrowca, który zgubił mapę, tym samym powracając do myśli Z. Baumanna, przywołanej na początku książki. Tym razem zostają wytyczone „obszary zagubienia" (s. 290) kobiet niepełnosprawnych: „W przestrzeni” (s. 290) - zmiana percepcji przestrzeni, „w czasie” (s. 291) koncentracja na teraźniejszości oraz „wśród innych” - „zawężenie przestrzeni społecznej" (s. 291). Badaczka zwraca uwagę na to, jak kobiety oceniają niepełnosprawność i jak ta ocena wpływa na ich historie. Podkreśla, że niepełnosprawność to z jednej strony zagrożenie dla tożsamości, a z drugiej szansa rozwoju.

W niniejszej publikacji Agnieszka Wołowicz-Ruszkowska podjęła się ważnego i trudnego zadania - zgłębienia wycinka rzeczywistości społecznej, który został osnuty zasłoną milczenia. Niepełnosprawność - wraz ze swym najbardziej wstydliwym aspektem - cielesnością - jest konsekwentnie wyrzucana poza nawias rzeczywistości medialnej, kulturowej i społecznej. Co ciekawsze, wszelkie kampanie prowadzone na rzecz osób z niepełnosprawnością - kładąc nacisk na odmienność osób niepełnosprawnych - wzmacniają ów efekt, zamiast przyczyniać się do jego zatarcia. $\mathrm{W}$ ten sposób rośnie mur oddzielający niepełnosprawnych od reszty świata. Nie wiadomo, co kryje się za tym murem, jakie problemy i oczekiwania. Agnieszka Wołowicz-Ruszkowska, poprzez niniejszą pracę badawczą, przełamuje tę barierę, budując dla niepełnosprawnych kobiet otwartą przestrzeń, pozwalającą im na swobodne opowiedzenie własnych historii. Dzieje się to na dwóch planach - psychologicznym - w wymiarze jednostkowego doświadczenia każdej z Respondentek i społecznym - w wymiarze stworzenia pola badawczego i wypełnienia go zgromadzonymi treściami. Jeśli, jak zauważyła autorka badań, kobiety niepełnosprawne skazane są na "niewidzialność” (s. 174), to niniejsze badania stanowią próbę wydobycia ich z owej niewidzialności poprzez naukowe opisanie ich doświadczeń i udostępnienie opisu szerszemu gronu odbiorców.

Nie tylko sam akt zgromadzenia życiorysów i dokonania ich analizy zasługuje na uwagę. Warto dostrzec także sposób, w jaki badaczka spogląda na problematykę radzenia sobie $\mathrm{z}$ niepełnosprawnością. Tematem nie są bo- 
wiem biografie kobiet, ale ich tożsamość w kontekście ich biografii. Badaczka stawia pytanie, w jaki sposób niepełnosprawne kobiety tworzą narracje o własnym życiu i niepełnosprawności przez pryzmat trajektorii. Ten zabieg podnosi wartość badawczą pracy, bowiem śledząc mechanizmy kształtowania się tożsamości u niepełnosprawnych kobiet, dochodzimy do ogólniejszych prawd dotyczących mechanizmów tworzenia się tożsamości.

Kolejną zaletę omawianej pracy stanowi podwójna perspektywa, z jakiej autorka spogląda na kobiety niepełnosprawne. Przede wszystkim jest to właśnie perspektywa podmiotu narracji, czyli subiektywna wizja siebie i świata zawarta w sposobie konstruowania i prowadzenia narracji. Perspektywa ta daje możliwość ukazania badanego fragmentu świata społecznego jako wypadkowej punktów widzenia wielu osób, co pozwala pogodzić naukowy obiektywizm z subiektywizmem podmiotów przedstawianych tu historii oraz jednostronność spojrzenia poszczególnych osób z wielowątkowością rzeczywistości społecznej. Mimo koncentracji na podmiocie narracji - niepełnosprawnej kobiecie, badaczka nie poprzestaje na tym spojrzeniu, udaje się na grunt antropologii i socjologii, by tam szukać zjawisk i prawidłowości kulturowych, które wpływają na kształtowanie się tożsamości kobiety niepełnosprawnej. Przykładem takiego postępowania jest rozpoczęcie rozdziału poświęconego cielesności kobiet niepełnosprawnych analizą sposobu istnienia ciała w otaczającej rzeczywistości kulturowej i społecznej. Zabieg ukazania ciała jako tekstu kultury pozwala spojrzeć na omawianą problematykę w szerszym kontekście, a jednocześnie uzyskać pogłębiony obraz cielesności pojedynczej kobiety niepełnosprawnej. Równie ciekawy wątek antropologiczny to ukazanie związku pomiędzy sytuacją kobiet niepełnosprawnych a motywem „włóczęgi” Z. Baumana. Wątek ten, pojawiając się na początku książki w rozdziale teoretycznym i powracając na końcu - w podsumowaniu badań stanowi klamrę spinającą całość. W odpowiedzi na koncepcję Baumana autorka wytycza i opisuje obszary zagubienia badanych "włóczęgów”. Użycie dwóch przeciwstawnych podejść, socjologiczno-antropologicznego oraz psychologiczno-narracyjnego pozwala na uzyskanie pełniejszego obrazu analizowanego wycinka rzeczywistości.

W niniejszej pracy zabrakło, moim zdaniem, rozwinięcia wątku niepełnosprawności jako szansy rozwoju. Badaczka zasygnalizowała, że część kobiet, dzięki pozytywnemu przepracowaniu trajektorii, doświadczyła ponownego otwarcia na świat. Należy się domyślać, że jest to możliwe jedynie dzięki uruchomieniu pewnych procesów myślowych, które nor- 
malnie nie zostałyby uruchomione, a które prowadzą do pogłębionego spojrzenia na siebie i innych. W tym sensie niepełnosprawność stanowi szansę rozwoju. Żałuję, że badaczka nie poświęciła więcej miejsca temu właśnie aspektowi, gdyż wydaje mi się on szczególnie interesujący w kontekście wcielania osób niepełnosprawnych do społeczeństwa, a także wykraczania poza sygnalizowany przez nią schemat litości i niechęci w kształtowaniu postaw wobec niepełnosprawnych. Zgłębienie aspektu rozwojowego niepełnosprawności wydaje mi się drogą ku niepełnosprawnym, szansą na zrównoważenie perspektywy, z której widzimy ich jako ułomnych, cierpiących i bezwolnych.

Agnieszka Wołowicz-Ruszkowska dokonała trafnego wyboru metodologii badań, decydując się na badania jakościowe, które, jak to określiła, stanowią próbę "oddania głosu” Respondentkom (s. 128). Pozwala na to metoda otwartego wywiadu autobiograficznego, umożliwiająca podjęcie tych tematów, które okazały się ważne dla samych Respondentek, w taki sposób, w jaki to czyniły Respondentki. Subiektywizm narracji o sobie i świecie - narracji, która stanowi jednocześnie przedmiot i metodę badań, współgra z wielowątkowością i niejednoznacznością podejmowanej problematyki kształtowania się tożsamości kobiet niepełnosprawnych. Wrażliwość badaczki na problemy Respondentek, jej ciepły stosunek do Badanych oraz gotowość do wysłuchania ich historii bez arbitralnie przyjętego schematu, o czym świadczy rezygnacja ze sporządzania kwestionariusza pytań, doprowadziła do stworzenia pełnego, barwnego i ciekawego obrazu rzeczywistości społecznej widzianej oczami kobiety z niepełnosprawnością. Jednocześnie, co wydaje się kluczowe, mimo tak swobodnej formy, jaką jest analiza wywiadów otwartych, rozprawa Agnieszki Wołowicz-Ruszkowskiej nie pozostawia wątpliwości co do swego naukowego charakteru. Autorka posłużyła się wybraną metodą analizy danych jakościowych, odpowiednią do podejmowanej problematyki. Jasno określiła sposób postępowania badawczego, opisując i uzasadniając podejmowane kroki, wytyczając cele badania i założenia badawcze, a także wyjaśniając, w jaki sposób wzmacniała trafność metody badawczej oraz rzetelność danych. Ponadto autorka skonstruowała bogatą, spójną z założeniami badawczymi oraz z przyjętą metodologią badań, ramę teoretyczną, wreszcie, dokonała wyraźnego rozgraniczenia pomiędzy częścią teoretyczną, metodologiczną i badawczą - czego badacze stosujący metody jakościowe nie zawsze przestrzegają. Wszystko to czyni omawianą pracę badawczą, a także całą rozprawę, niezwykle przejrzystą i wiarygodną. 
Książka Agnieszki Wołowicz-Ruszkowskiej porusza ważny i trudny temat. Ukazuje rzeczywistość niepełnosprawnych kobiet $\mathrm{z}$ ich własnej perspektywy - z pozycji kobiet potrójnie zagubionych - w przestrzeni, w czasie oraz wśród ludzi. To spojrzenie zostaje przeciwstawione szerszemu spojrzeniu, antropologicznemu, które stanowi punkt wyjścia, a jednocześnie dopełnienie ukazanej przez badaczkę subiektywnej perspektywy podmiotu autobiograficznej narracji. Niniejszą rozprawę uważam za godną polecenia ze względu na wagę poruszanych problemów oraz ze względu na sposób ich ujęcia, co szczegółowo opisałam we wcześniejszych akapitach. Praca ta stanowi też świetny przykład dobrze przeprowadzonych i przedstawionych badań jakościowych, zawierających czytelną metodologię, spójną z założeniami badawczymi, a także ugruntowaną $\mathrm{w}$ teorii za pomocą koncepcji socjologicznych, psychologicznych i antropologicznych. Jednocześnie uważam, że publikacja Zanikanie powinna trafić nie tylko w ręce osób o zainteresowaniach naukowych, ale także do szerszego grona odbiorców, ponieważ zawarte w niej treści mają charakter ogólnoludzki. 